Chicago-Kent College of Law

Scholarly Commons @ IIT Chicago-Kent College of Law

January 2001

\title{
Sculpting the Agenda of Comparative Law: Ernst Rabel and the Façade of Language
}

David J. Gerber

IIT Chicago-Kent College of Law, dgerber@kentlaw.iit.edu

Follow this and additional works at: https://scholarship.kentlaw.iit.edu/fac_schol

Part of the Antitrust and Trade Regulation Commons, Comparative and Foreign Law Commons, and the International Law Commons

\section{Recommended Citation}

David J. Gerber, Sculpting the Agenda of Comparative Law: Ernst Rabel and the Façade of Language, (2001).

Available at: https://scholarship.kentlaw.iit.edu/fac_schol/247

This Contribution to Book is brought to you for free and open access by the Faculty Scholarship at Scholarly Commons @ IIT Chicago-Kent College of Law. It has been accepted for inclusion in All Faculty Scholarship by an authorized administrator of Scholarly Commons @ IIT Chicago-Kent College of Law. For more information, please contact jwenger@kentlaw.iit.edu, ebarney@kentlaw.iit.edu. 


\title{
7 \\ Sculpting the Agenda of Comparative \\ Law: Ernst Rabel and the \\ Facade of Language
}

\author{
DAVID J. GERBER
}

The method developed by Ernst Rabel for the comparative study of law has acquired the status of orthodoxy in much of the world. His so-called function/context method has dominated much of the work done in comparative law since the Second World War. Yet what kind of orthodoxy is it? What was he trying to do and how did he seek to accomplish his goals? Answers to these questions illuminate the tensions and forces within comparative law today and suggest paths for its future development.

My central objective in this essay is, therefore, to seek answers to these questions. I try to locate Rabel's project and identify some of the principal factors that influenced his goals and shaped his methods. The aim of this analysis is to set the stage for "rethinking" Rabel's methods and their relationship to the contemporary needs of comparative law.

Language is a prominent theme in this story. Rabel's vision of comparative law was defined by both a distrust of language and the need to use it in particular ways to achieve his goals. He sought to penetrate beneath language to a more "concrete reality," while at the same time focusing much of his professional attention on interpreting the formal and often abstract language of legal texts and on preparing the porous and opaque language of international agreements. This tension is central to his methods - a source of both value and constraint.

Educated in turn-of-the-century Vienna, Rabel shared many of the experiences that sensitized Ludwig Wittgenstein and others of his generation to the inadequacy and deceptiveness of language. These experiences led him to distrust the direct comparison of concepts, doctrines and texts that had been the standard methodology of comparative law. Meaningful comparison could be achieved, he argued, only by reference to the underlying social problems to which the language was related. This was his great insight and the core of the methodology he generated.

Yet Rabel's professional goals and projects shaped the ways in which that methodology was understood and used, and they depended on particular uses of language. In the desperately hopeful context of the 1920 s, scholars, politicians, 
bureaucrats and even some business leaders were seeking words that would somehow protect what was threatened and at the same time save the world from chaos and destruction. It was a heavy burden for language to bear, and the effort to bear it has had a profound effect on the development of comparative legal studies.

I first look briefly at the road that led Rabel to comparative law and some of the factors that shaped both his expectations and the mental tools that he brought to the enterprise. I then focus on his principal writings in comparative law and the forces that shaped them. In the final sections of the essay, I turn to the sources of Rabel's influence and to its roles and potential today.

THE PATH TO COMPARATIVE LAW

\section{Vienna}

Born in Vienna in 1874, Rabel was raised and educated in the extraordinarily fertile intellectual milieu that that city produced in the decades bracketing the turn of the century.' He was a member of a sophisticated German-speaking urban elite often referred to as the "liberal" upper middle class or just "the liberals." His father was a successful lawyer, and Rabel followed in his father's footsteps by studying law. On one level, then, he grew up securely part of an educated elite in a powerful and apparently stable world capital. ${ }^{2}$

There was, however, a darker side to the picture. During the 1890 s, this elite was increasingly attacked by other social classes as well as by nationalist groups in many parts of the Hapsburg Empire who sought more rights and more power within the Austrian system. As such groups grew stronger and bolder, they disrupted Austrian political and social life.

It was a conflict in which language was both culprit and target - a marker of tension, and a focus of resentment. German was the language of dominion and control in the empire. It was the language not only of the liberal elite, but of the aristocracy and of government. Nationalist groups thus focused on achieving respect and status for their own languages. As Carl Schorske has put it,

\footnotetext{
I Sigmund Freud was reshaping thought about the human psyche; Gustav Mahler and Amold Schoenberg were creating new forms of music; Carl Menger and Eugen Böhm-Bawerk were developing a fundamentally new appronch to economics; and Ludwig Wittgenstein was preparing to chart a new course for philosophy. For evocations of the Austrian intellectual milieu during this period, see Carl E. Schorske, Fint-de-Siecle Vienna (New York, 1980); Alan Janik \& Stephen Toulmin, Witigenstein's Vienna (New York, 1973); and Mark Francis (ed.), The Viennese Enlightentment (London, 1985).

2 Biographical details of Rabel's early life are sparse. For general biographical discussions that include information on this period, see, e.g., Gerhard Kegel, "Ernst Rabel-Werk und Person," 54 Rabels Zeitschrift I (1990); Ernst Julius Wolff, "Erust Rabel," 73 Savigny Zeitschrift, Röm. Abr. X-XXVIII (1956) and Max Rheinstein, "In Memory of Ernst Rabel," 5 Am. J. Comp. L. 185-196 (1956).
} 
"The liberals had conjured up new forces and new claimants to political participation: Slavic nationalists, Socialists, Pan-German anti-semites, Christian Social anti-semites. They neither integrated these new movements into the legal order nor could they satisfy their demands. The conflicting groups may have had different heavens, but they shared the same hell: the rule of the Austro-German liberal middle class." 3

Thus social, ethnic and religious resentments were all projected onto the "liberal" class and the linguistic hegemony that defined and represented it,

As a result, members of the liberal class were caught between awareness of these disintegrative forces and the desire to protect their own status and values. The role of language in the conflict also made many among them both acutely conscious of language and dubious about its roles. This conflict and the tensions it produced help us to understand the development of Rabel's aims and methods.

\section{Legal Education}

While studying law at the University of Vienna, Rabel came under the influence of Ludwig Mitteis, a leading legal historian, particularly of Roman law. It was an influence that would shape the rest of his life. After he finished his basic legal education, Rabel entered law practice with his father, but he soon decided to follow Mitteis to the latter's new position in Leipzig. He there became a legal historian, receiving his doctor's degree in 1899 and his "Habilitation" in 1902.

Years later Rabel praised his master's influence, emphasizing the latter's discipline and methodological precision. "More than anything else . . . his scientific discipline was a model for me." ${ }^{5}$ Rabel ascribed much of his own style and method in comparative law to this historical training. The main objective of Mitteis' method was to identify and understand the functions of the classical legal doctrines and institutions, and from there it "was only an additional step to apply the same method to the comparison of modern systems." 6

\section{Rabel as Historian}

Rabel achieved renown as a legal historian, primarily of Roman and French law, and this led to a quick succession of calls to German and Swiss universities. In

3 Schorske, supra note 1 , at 303.

"For a recent, detailed study of the Mitteis "school" and its influence on Rabel, see Reinhard Zimmermann, "In der Schule von Ludwig Mitteis," Rabels Zeitschrift 1 (forthcoming, 2001).

$s$ Ernst Rabel, "In der Schule von Ludwig Mitteis," 7-8 J. Juristic Papyrology 157 (1954). The collected articles of Ernst Rabel have been published in 4 volumes. See Hans G. Leser (ed.), Ernst Rabel, Gesammelte Aufsätze: vols. 1 and 2 (Tübingen, 1965); Hans G. Leser (ed.), vol. 3 (Tübingen, 1967); Hans Julius Wolff (ed.), vol. 4 (Tübingen, 1971). Because these volumes are difficult to obtain in the U.S., I have generally cited to originals (some of which, of course, are also difficult to obtain in the U.S., but some of which are not).

6 Rabel, "In der Schule," supra note 5, at 159. 
assessing Rabel's professional development, it is important to remember that Roman law played a far greater role in early twentieth century Germany than it does today. It was still seen as an important source of guidance in legal thinking and of solutions to current problems, and this influence was far more direct and extensive than we can easily imagine. Rabel's transition from legal historian to comparatist did not, therefore, traverse as much attitudinal status and institutional distance as such a move would today.

THE COMPARATIVE LAW PROJECT: RABEL'S ROLES AND CONTEXTS

After his call to the Munich law faculty in 1916, Rabel changed his focus from legal history to comparative law. His major writings on comparative law date from the period between 1916 and 1939, when he was forced to flee Germany. Our discussion will focus on these two turbulent decades, and this requires a brief glimpse at the contexts in which Rabel operated.

\section{Contexts}

One context was European-the general loss of confidence in European civilization and responses to that sense of loss. The Great War had dissolved confidence in Europe's leadership and in many of the ideals and methods associated with it, creating a powerful tension between dissolution and hope that pervaded the intellectual and political life of the period. ${ }^{7}$ At one pole was societal disruption and the fear that it would escalate. In some countries (e.g., Russia and Germany) fundamental changes had actually occurred. In others (e.g., France) changes were less dramatic, but fear that society's bonds were dissolving was widespread, particularly within the middle classes. The other pole saw an extraordinary surge of hope that international institutions could prevent future disasters. During the second half of the $1920 \mathrm{~s}$, for example, many placed their hopes in new international institutions, organizations and conferences designed to create a new "world society."

In Germany, defeat and the physical and psychological devastation of war joined with postwar political unrest and disruption to explode even rudimentary expectations of stability for much of the period. Crises and instability were prominent during the Weimar years, as were rancour and distrust of "the West," much of it associated with the handling of reparations issues.

Sharp and generally growing tensions between political groups squeezed Germany's educated elite. As a resule of the war and the postwar political turmoil, the "Mandarin" class had lost much of its status and economic security. Its members increasingly identified themselves as victims of political conflict and

7 See,e.g., Paul Fussell, The Great War and Modern Memory (Oxford, 1975), 
acknowledged the need to band together as a class to protect their interests and regain their lost prosperity. ${ }^{8}$

Rabel's primary professional milieu - the German university-was also riddled with uncertainty and disruption. The war had undermined the exceptionally high status of the professoriate. The postwar currency crisis then further devastated educational budgets, and the weakness of Weimar government prevented significant improvements in the social status or financial situation of many professors.

In the university in Berlin, where Rabel taught after 1926, financial insecurity was accompanied by fears for personal security. Ernst von Caemmerer, later one of Rabel's most influential disciples, reported to me that when he went to Rabel's institute in Berlin in the late 1920s he not infrequently encountered gunfire outside the university - skirmishes between rightwing and leftwing groups.

The intellectual milieu reflected this turbulence. It was a period of widespread experimentation with new perspectives and of frequent battles between those who experimented and those who insisted on the primacy of established methodologies and perspectives. In disciplines related to law such as economics and sociology, the historicism that had helped to shape a vision of Germany's "specialness" had been largely discredited, leaving a widespread sense of uncertainty about the role and characteristics of scholarship.

In law itself, the situation was particularly complex. The German legal profession had spent the last two decades of the nineteenth century preparing a new civil code and the first decade and a half of the twentieth examining the code it had created. This had many consequences, not the least of which was to ingrain text-centered habits of thought. The positivism of the prewar period remained powerful, although it was increasingly criticized in academic circles, where emphasis was shifting toward finding new ways of interpreting the code based on the interests thought to be represented by its language. ${ }^{10}$

Rabel bemoaned, in particular, Germany's loss of intellectual leadership in law. German legal scholars were woefully unaware of and uninterested in what was happening elsewhere, he claimed, and as a result their work was no longer as important as it once had been. This was especially true, he believed, in private law. In that area, he wrote, "we have to regret the 'greatest' backwardness and lack of development."

* The classic account is Fritz Ringer, The Decline of the German Mandarins: The German Academic Community, 1890-1933 (Cambridge, Mass., 1969).

$\rightarrow$ For detailed recent discussion of the intellectual developments in law and the social sciences during this period, see Knut Nörr et al. (eds.), Geisteswissenschaften zwischen Kaiserreich und Republik (Stuttgart, 1994).

to See gen. Karl Larenz, Methodenlehre der Rechtswissenschaft, 36-117 (5th ed., Berlin, 1983) and Max Rheinstein, "Comparative Law and Conflict of Laws in Germany," 2 U. Chi. L. Rev. 232 (1935). See also Kennerh Ledford, From General Estate to Special Interest: German Lawyers 1878-1933 (Cambridge, 1996).

"Ernst Rabel, "Das Institut für Rechtsvergleichung an der Universität München," 15 Zeitschrift fir Rechtspflege in Bayern 2, 3 (1919). 


\section{Rabel's Roles}

Rabel was active in many arenas. He was not only a university professor and institute director, but also a judge, an arbitrator, and an advisor to German business. ${ }^{12}$ In the academic world, Rabel was a rapidly rising "star" when he was appointed professor of law in Munich. He had risen to prominence primarily as a legal historian, but in Munich he quickly achieved prominence in comparative law, a field which was just taking shape. Ten years later his preeminence in that field was confirmed when he was named director of the newly-created Kaiser-Wilhelm Institute for Foreign and International Private Law in Berlin, the most prominent position in comparative law in Germany. ${ }^{13}$ This institute had both private and public funding and both private and public goals. It was one of several scientific institutes intended to foster the development of scientific knowledge by German scientists, but it was also intended to provide advice to German industry and government officials in their dealings with the West. It gave Rabel exceptional influence and power within the academic legal profession, and it also tied him to German government and business interests.

Rabel also gained extensive international experience during this period. From the end of the First World War until shortly before he left Germany, he participated actively and prominently in several important international institutions, and his activities there shaped the way he understood comparative law and its potential roles. They led him to an agenda in which "science" was to be applied in practical dispute resolution contexts. According to von Caemmerer, he often emphasized the importance of his broad range of practical experiences in the development of his approach to law.

One of those roles was as a judge/arbitrator. In the early 1920 s, he frequently served on the so-called "Mixed Arbitral Tribunal Panels" that heard disputes under the provisions of the Versailles Peace Treaty. ${ }^{14}$ These tribunals had jurisdiction over disputes involving pre-war contracts between Germans and others and over harm caused by certain war measures. Each tribunal consisted of three judges: one neutral, one Allied, and one German. The tribunals were highly controversial, particularly in Germany, where rulings, particularly in the early years, were often adverse to German interests and, therefore, often seen as indications that the tribunals were not "fair." In the late 1920 s, Rabel was also an ad hoc judge on the Permanent Court of International Justice in several prominent cases.

\footnotetext{
12 He was a judge on a court of appeals in Basel (1907-1910) and in Munich (1920-1925) and on the Permanent Court of International Justice (1925-1928); he was also a judge/arbitrator on the German-Italian Mixed Arbitration Tribunal (1921-1927). For further discussion, see Hans G. Leser, "Einleitung," in I Ernst Rabels, Gesammelte Aufsätze XVIII, XIX (Tübingen, 1965).

${ }^{13}$ For descriptions of the institute and its operations, see Rheinstein, "Comparative Law," supra note 10, at 244-5. See also Ernst Rabel, "On Institutes of Comparative Law," 47 Colwm. L. Rev. 227 $(1947)$.

${ }^{14}$ For discussion, see Ernst Rabel, Rechtsvergleichung vor den Gemischten Schiedsgerichtshöfen (1923).
} 
Rabel was also heavily involved in international legal unification projects. $\mathrm{He}$ was, for example, an active member of the League of Nations' institute for the unification of law in Rome. The most important of these projects was, however, the mandate that Rabel received from the League of Nations to create the basis for a unified international sales law. This undertaking led him to investigate systematically the sales laws of the major trading states. His meticulous and insightful comparison of the world's sales laws was highly praised, and it was the basis for his extraordinarily influential study of sales law, the first volume of which was published in $1936 .{ }^{15}$ This work was in many ways a kind of "bible" for the efforts after the Second World War to unify sales law that eventuated in the Vienna Convention on the International Sale of Goods.

\section{LAW, DISSOLUTION AND HOPE: RABEL'S STATED AIMS}

When exploring Rabel's aims, we need to locate them in relation to the powerful, almost "messianic" discursive field that dominated thought in international political circles in the late 1920 s. During those years, many were desperately seeking to repair the shattered confidence in European institutions and stave off the threats of further dissolution, and they often saw international institutions as the most promising-perhaps the only-mechanism for achieving those aims. There was a profound belief among many of those involved in international institutions that they were "saving the world from destruction," and this desperation-hued hopefulness was a major animating force within many of those institutions.

Consistent with this ethos, Rabel saw comparative law in large terms-as part of the solution to the fundamental problems that were facing Europe, in general, and Germany, in particular. As he put it, "Here is the most important point where the comparative law comes in. We must come back to an international treatment in an international spirit of international problems." 16 To that extent, we need to use a different lens in interpreting his objectives than we would typically use today. I suspect that few of those of us engaged in comparative law research today believe that the future of the world rests to any significant degree on our professional activities. Even if we did, few others are likely to agree.

In locating Rabel's project, we also need to be clear about his conceptualization of comparative law as a subject. He refers to three separate components of the comparative law enterprise. ${ }^{17}$ One was historical, the study of how different

is Ernst Rabel, Das Recht des Warenkaufs (vol 1., Berlin, 1936; vol. 2, 1957).

16 Jürgen Thieme, "Ernst Rabel (1874-1955): Schriften aus dem Nachlass," 50 Rabels Zeitschrift, 251, 305 (1986). See also Ernst Rabel, "Aufgabe und Notwendigkeit der Rechtsvergleichung," 13 Rheinische Zeitschrift fur Zivil-und Prozessrecht 279 (1924).

17. See Ernst Rabel, "Das Insitut," supra note 11, at 2-3. There were some variations in the descriptions of these components over time. See, e.g., Rheinstein, "Comparative Law," supra note 10 , at 250 . 
legal systems evolved, particularly in relation to each other. This was his focus during the first part of his career. A second focused on existing legal systems and differences in how they operated. This was his focus after 1916, and it is the subject of our inquiry. A third bordered on philosophy and sought to see the larger meaning of the other two. Rabel never developed this vague third category. ${ }^{18}$ Our subject matter here then is only a part of Rabel's broad conception of comparative law.

\section{Pure Science}

Rabel claimed that the central goal of comparative law was "pure science" - the search for knowledge (Erkenntnis). ${ }^{19}$ It was central in the sense that all else flowed from it: specific uses of comparative law were conceived as "applied" science. But Rabel's references to science are remarkably unspecific. He was never very clear about what he meant by the term, perhaps because it was part of a shared "background understanding" and therefore did not require attention. Often he seems to mean little more than the disciplined, self-conscious, and careful search for knowledge.

For Rabel, the subject of this scientific investigation was the Rechtssatz (roughly, legal rule or norm). ${ }^{20}$ "Legal comparison means that the legal rules (Rechtssätze) of one state (or orher law-prescribing community) are analyzed in relation to those of another legal order - or as many such orders as possiblefrom the past and the present." 21 The basic reference point is the rule or norm itself-not the process of creating, interpreting or applying it.

\section{Applied Science}

Although Rabel conceived his comparative law methods as science, his writings repeatedly emphasize their practical utility, and this theme became (and remains) a prominent part of the discourse used by his students and followers,

\footnotetext{
18 In an article published in 1919, he described this third component as follows: "a component that penetrated philosophy, where historical and systematic legal science, together with legal philosophy, examine the deepest issues of the evolution and impact of law." Rabel, "Das Institut," supra note 11 , at 2 .

19 For discussion of German legal science, see, e.g., Mattias Reimann, "Nineteenth Century. German Legal Science," 31 B. C. L. Rev, 842 (1990).

20 The term "Rechtssatz" is difficult to translate into English. "Legal rule" is probably the closest translation, and that is what I will normally use here, but the German term does not carry the connotations of narrowness associated with the term in English. The reader should think of it as an "authoritative legal proposition." Rabel himself pointed out that a Rechtssatz is not the same as a rule or principle in U.S. law. See Ernst Rabel, "Die Fachgebiete des Kaiser-Wilhelm-Instituts für Ausländisches und Internationales Privatrecht (Gegründet 1926) 1900-1935," in Rabel (ed,), Gesammelte Aufsätze, supra note 12, at 180, 191.

21 Rabel, Aufgabe, supra note 16, at 280.
} 
particularly in Germany. This combination of academic and practical concerns shaped his methods and distinguished them from those of his predecessors and competitors. In seeking to be simultaneously both scientific and practical, he sought to stake out a unique position in both the academic and policy/practice communities.

One set of applications related to policy. Rabel wanted to create tools that would make better lawyers and better law. His methods were intended to make lawyers more capable of understanding the foreign legal situations they faced and better able to respond to them effectively. ${ }^{22}$ They required students to immerse themselves in the details of specific situations and thereby develop a more effective and valuable knowledge of how such situations were treated in other legal systems.

They were also intended to produce better law. They were to be used, for example, to clarify the concepts of legal language and thereby make that language sharper and more effective. ${ }^{23}$ In addition, they were to improve the "store of solutions (Vorrat an Lösungen)" to societal problems available to decision makers and thereby lead to better solutions to those problems. ${ }^{24}$

But Rabel frequently also referred to the value of his methods in gaining competitive advantages for Germany, German business and German lawyers. He wanted to make the German practitioner better able to understand the contexts in which he was operating, so that he could "win" his battles with his Western competitors and thus also serve Germany's economic and political interests. In 1919 he wrote "The reconstruction of the fatherland and its strengthening visa-vis the outside world require a sharpened perception of the events of the world. The new tasks must also find the lawyers (Juristen) armed." 25 There is a strong strand of nationalist pride in Rabel's writings during the 1920s.

LANGUAGE AS BOTH FACADE AND RESPONSE: COMPARATIVE LAW'S METHODS

Rabel's methods reflect these goals. Method, in the broad sense of thinking carefully about how one achieves a set of goals, was important to him. He repeatedly refers to it, those who worked for him often refer to his focus on method, and later commentators have recognized it. We might expect him, therefore, to have carefully and self-consciously elaborated his methodology. He did not, at least in his published writings. ${ }^{26}$ Ironically, there is little method in his method.

22 See, e.g., Rabel, "Das Institut," supra note 11 , at $25-8$.

23 See, e.g., Rabel, Aufgabe, supra note 16, at 285, where he refers to the "cleansing" or "purification" (Reinigung) of legal concepts.

$24 \mathrm{Id}$. at 287.

25 Rabel, Das Institut, supra note 11, at 6.

26 For extended discussion of Rabel's methodology, see Hans G. Leser, "Ein Beitrag Ernst Rabels zur Privatrechtsmethode: 'Die Wohltätige Gewohnheit, den Rechrsfall vor der Regel zu Bedenken,' " in Hans Ficker et al. (eds), Festschrift für Emst von Caemmerer 891 (Tübingen, 1978). 
His "methodology" consisted of little more than a set of general claims about the characteristics of scholarship that would serve the goals he had identified. In style, his methodology is close to the historicist methodology in the social sciences that was prominent in Germany from the 1880 s until the First World War. ${ }^{27}$ "Method" was there a matter of careful attention to patterns and details in the operation of society and economy. It eschewed-even condemnedtheoretical development of methodological principles.

\section{Function and Context: How to do Comparative Law}

Rabel's prescription for the comparatist was, in its essence, simple: look at how a problem is solved in two or more legal systems and explore the differences and similarities in the respective treatments of the problem. He summarized his project as follows: "Rather than comparing fixed data and isolated paragraphs, we compare the solutions produced by one state for a specific factual situation with those produced by another state for the same factual situation, and then we ask why they were produced and what success they had." 28 In this basic form, the prescription appears simplistic, but it was a new way of thinking about the field, and there was much embedded beneath the apparently simple surface. Rabel's methodology is today often referred to as the function/context method. This linguistic coding appears to have been done by his students rather than by Rabel himself, but it captures the basic structure of his method.

\section{Function}

For Rabel, the essence of his methodology was its focus on the concrete, its drive to get behind the facade of language. In his view, information about a foreign legal system was only valuable in so far as it was contextualized. The written text should not structure the analysis, because conceptual and linguistic analyses of the articulated norms of a foreign legal system had little value by themselves. Taken alone, the formal language of rules and principles explained little about how problems were actually solved in the foreign system, and thus to structure analysis around language was likely to obscure rather than illuminate what was happening. The way to acquire relevant information about a foreign legal system was to ask how such rules and principles related to a specific fact situation. What counted was how the norms were applied. In this sense, he was "stripping the facade" of language away from legal reality. It was a pointed rejection of "speculative" and positivist visions of comparative law, both of which focused on that formal language. ${ }^{29}$

\footnotetext{
27 For discussion and references, see David J. Gerber, Law and Competition in Twentieth Centisty Europe: Protecting Prometheus, 29-31 (Oxford, 1998).

28 Rabel, Fachgebiete, supra note 20, at 187.

29 See infra, text accompanying notes $32-4$.
} 
He thus shifted the methodological focus to the specific social functions of rules, which were to serve as the terra comparationis. ${ }^{30}$ It was the mechanism that allowed meaningful comparison. Each system treated specific problems in specific ways, and thus the starting point of analysis should be the problems themselves. Rabel changed the structure of the analysis, moving the focus from the formal language of the system's rules and principles to the concrete reality (function) to which those rules and principles related. Note, however, that his objective was still to understand how the rules worked. The difference was that now rules were studied in relation to a specific problem rather than as the center of the investigation. It was a fundamental shift of conceptual field.

\section{Context}

The function/context label suggests that function and context are separate and independent analytical functions, the former to be performed before the latter. In Rabel's writings they are not so clearly distinguished. The conceptual boundary is far more fluid. For him, both components of the analysis flow from the same basic methodological injunction to look at how systems handle specific problems. The analyst has to understand the function-the concrete reality-to which legal norms relate, but she can do so only by looking at what they do in context. Cognitively, the two operations are intertwined.

Nevertheless, "context" did come to be treated in later writing as distinct, and analytically the distinction has value. Rabel insisted that in order to understand how each system treated a particular problem and thus produce an adequate and effective comparison, one had to investigate the entire context. The scope of the analysis was thus - in principle, at least-virtually unlimited in scope.

Curiously, however, Rabel provided little guidance for analyzing context. The analyst was supposed to look at all the factors that influenced the norms and procedures that addressed a particular problem, but Rabel did not concern himself with how this was to be done. Presumably he thought this was just a matter of looking for factors that might influence the application of the norms involved, but the omission is striking. What should the analyst be looking for? Are there patterns of decision making that help interpret particular decisions? Rabel's methodology is silent on such questions. The value of context is affirmed, but it is left largely unattended. ${ }^{31}$

\footnotetext{
30. One might expect this move to have been tied to developments in social science or to the influence of social science, but I have found little evidence that Rabel paid much attention to social science developments.

31 One clue to interpreting the role of context was Rabel's perception of the need for reciprocating movement between the specific and general. This was a prominent trope in academic circles of the period. Context was the broader lens, function the narrower one. The comparatist should use the narrow lens of function to see the specific problem to which norms were related, but he had to use the broader lens of context to make the comparison. The interaction between the two perspectives legitimated the analysis.
} 
This lack of attention may relate to the institutional embeddedness of Rabel's methodology. From his early writings on comparative law, he conceived comparative law as an undertaking of large proportions in which many specialists would be responsible for amassing great amounts of knowledge relating to specific situations. It involved massive data-gathering. His comparative law institute in Munich moved in this direction, but it was at the Kaiser Wilhelm Institute in Berlin that he created what he claimed was needed-a large, wellendowed facility with large numbers of specialist researchers and extensive research materials. This institute was the centerpiece of his career.

\section{Shaping Factors}

Rabel defined his own methods in contradistinction to the two methods that were most prominent in the field at the time, claiming that both were inadequate to the tasks of the day. One was a kind of speculative jurisprudence of comparison. ${ }^{32}$ He believed that comparative law had been too abstract and too philosophical. Scholars had looked at general features of large numbers of systems and drawn general conclusions about the relationships among them. This produced compendia in the style of the "laws of the world," but Rabel saw it as having little value in the "real world" of law. For him, comparison was only useful if it was "grounded" in the realities of the way legal systems actually solved problems. ${ }^{33}$

He was at least as adamant that comparative law was of little value if it merely compared statutory texts. To know the text of a statute was generally of little value if one did not know how the courts and other legal professionals were likely to interpret and use it. ${ }^{34}$ Today this point seems trivial, at least to academic legal comparatists, but at the time much of what was called comparative law work was done in that vein. In contrast to this arid and potentially misleading textual orientation, Rabel set out to base his comparison on "living law."

Rabel viewed his methods as essentially - even radically - new. He acknowledged that a few other scholars had worked in the same direction, notably the Frenchman Edouard Lambert. ${ }^{35}$ In this context, however, he did not refer to scholars other than his former teacher Ludwig Mitteis as authority or acknowledge their influence on the development of his comparative law methods. ${ }^{36}$ Given the importance of context in his methodology, one might suppose that he would refer to social scientific literature, but he seldom did.

32 For discussion, see, e.g., Rheinstein, Comparative Law, supra note 10, at 234.

3. Recall that he envisioned broader philosophical study of comparative law as a distinct third component of the comparative enterprise that could be usefully engaged in only after adequate development of the functional, doctrinal issues. Cf. supra, text accompanying note 17 .

34 Rabel, Aufgabe, supra note 16 , at 282.

35 Id. at 4, n.5.

36. For discussion, see supra, text accompanying notes $4-6$. 
At one level, Rabel's goals-both private and professional-shaped his methods. On the professional level, for example, the many legal unification projects in which he was involved created incentives to amass large amounts of information about the treatment of specific problems in specific countries and then create treaty language that would encompass the solutions of the systems involved. His method was particularly well-suited to that enterprise, and it seems likely that the development of the methodology was intentionally designed for that type of use. His methods also answered the many choice of law issues that Rabel confronted in his judicial and arbitral roles. In these contexts, he had to decide which norms were applicable to which specific fact situations, and his method identified the relevant rules and principles. One further example relates to the practical needs of the German businesses and cartels that were desperately competing for international business during the 1920s (and who were in part funding Rabel's institute). For them, the earlier forms of comparative analysis had little value, but Rabel's methods provided specific answers to the specific contract, tort and other private law issues they faced. For these types of functions, Rabel's methods were beneficial and attractive.

These methods also provided benefits for Rabel personally. For example, his emphasis on "rending the veil" of language positioned him as an exceptional intellect who had penetrated the appearances of life to reveal its core and enhanced his status within intellectual circles. Furthermore, as an intellectual in a time when intellectuals had lost some of their status and much of their economic security, his methods helped to make him and his field "relevant" and hence valuable to those outside the university without abandoning the standards of academic discourse. They made Rabel an intermediary between the academic world and the needs of German business and politics, and they attracted the support of both.

In this brief essay, I cannot examine in detail the intellectual influences on the shaping of his methodology. It is important to note, however, that the idea of penetrating "beneath the surface" of conventions and language to a more concrete realm of "phenomena" was a prominent theme of the period. This was, for example, the basic thrust of the highly influential writings of the philosophers Edmund Husserl and Martin Heidegger. Rabel's methods can also be seen as part of a broader movement in law that focused on the "purpose" behind statutory provisions as a tool for interpreting and applying them. ${ }^{37}$ Finally, Rabel's extensive study of U.S. law apparently led him to emphasize the importance of case law and the need to attend carefully to the details and contexts in which legal rules operated. ${ }^{38}$

\footnotetext{
57 See Leser, Beitrag, supra note 26 , at 905 . This "movement" began with the influential writings of Rudolf von Jhering in the late 19th century and continued with the "Tübingen school" of "interest jurisprudence" in the early 20 th century. For discussion, see Larenz, supra note 10, at 43-58.

38 See Ernst Rabel, "Deutsches und Amerikanisches Recht," 16 Rabels Zeitschrift 340 (1951).
} 
THE ROAD TO ORTHODOXY

My primary aim in this essay is to shed light on Rabel's methods, but the path that led to the successes and the eventual orthodoxy of those methods cannot be separated from the project itself. It provides the perspective from which we today look at Rabel's project, and thus we need to sketch it, albeit briefly.

Rabel's methods must have been "heady stuff" for his students. In the contexts of the Weimar period, they must have found it exciting to be part of an "intellectual breakthrough" that also promised a new kind of relevance for their academic efforts. It cast them as the "new breed" that dealt with reality rather than with the arid speculations of academic theorists or the equally dry parsing of statutory language. It made legal science intellectually challenging as well as immediately relevant to groups outside the academy such as businessmen and politicians, and this, in turn, also provided pecuniary and status-enhancement incentives. Little wonder that they were enthusiastic about it.

After the war, the popularity of the method grew even greater, although Rabel himself played only a marginal role in postwar developments. As a converted Jew, he had been forced to emigrate to the United States in 1938, and he chose never to return permanently to Germany. For his earlier efforts and influence he was honored with prizes and visiting professorships there, but he was not again a direct personal force in German comparative law. His methodology acquired the status of orthodoxy there because devoted students of Rabel such as Ernst von Caemmerer and Gerhard Kegel acquired leadership positions in comparative law in postwar Germany and continued to rely on Rabel's methods and discourse, and because they received support from other former students such as Walter Hallstein who became important political leaders. These former students formed a leadership community for which Rabel's methods served as the intellectual core and which has been passed on to subsequent academic generations with little apparent diminution in force.

Rabel's methodology also achieved a kind of orthodoxy in United States academic comparative law circles after the war. ${ }^{39}$ Again, however, it was through his disciples and their influence rather than through his own influence. Rabel was sixty-five when he came to the U.S. in 1939. He knew English, but apparently he was not particularly comfortable with spoken English. He did research at Harvard Law School and the University of Michigan, but he was too old to become a faculty member. Although he managed to publish widely in leading journals, he remained a marginal and relatively isolated figure.

However, several of his closest disciples became leading figures in comparative law in the United States after the war, These included, in particular, Friedrich Kessler, who became professor of law at Yale Law School, and Max

\footnotetext{
39 For extended discussion of Rabel's influence in the United States, see David S. Clark, "The Influence of Ernst Rabel on American Law," in Marcus Lutter et al. (eds), Der Einfluss deutscher Emigranten auf die Rechtsentwicklung in den USA und in Deutschland 107 (Tübingen, 1993).
} 
Rheinstein, who was professor of law at the University of Chicago Law School. Many of the members of this group kept close ties to their counterparts in Germany, exchanging visits, sending students to each other, and participating in joint projects. Again, Rabel's methodology served as the intellectual bond of their expanded community.

IMPLICATIONS FOR LOCATING CONTEMPORARY COMPARATIVE LAW

This brief look at Rabel's aims, the methods he developed to achieve them and some of the factors that influenced both aims and methods helps locate comparative law today. The lenses that he fashioned have shaped our knowledge and our agendas, and thus we need to look both at what those lenses include and what they exclude. We can then ask how those characteristics correspond to today's needs. ${ }^{40}$

\section{Lenses: Components of the Knowledge Field}

\section{Artifacts}

One prominent characteristic of the knowledge produced by these methods is that it relates primarily and often exclusively to the artifacts of decision-making rather than to the process of creating those artifacts. His methods direct attention to rules and principles and propositions of law-products. They provide a means of identifying these products, abstracting them from the system in which they operate and then comparing the normative constellation of one system with another.

\section{Focus on Detail}

The knowledge produced by this method is necessarily detailed. Rabel focused on specific life-situations, comparing the ways in which different legal systems treated those situations. This requires attention to the details of those situations as well as to the details of the normative constructions being applied to them.

\section{Particularism}

Such knowledge is also particularist. By that I mean that it is largely independent of and unrelated to other knowledge; it is isolated. The method focuses the attention of the user on a particular problem and produces knowledge about that particular problem. This is not the province of theorizing, pattern identification or generalizations.

40. For additional discussion of some of these themes, see David J. Gerber, "System Dynamics: Toward a Language of Comparative Law?," 46 Am. J. Comp. L. 719 (1998). 


\section{Statics}

Finally, the knowledge is largely static. It relates to a specific normative configuration at a fixed point in time. The method creates a careful still photograph, a snapshot. It does not capture change over time, except incidentally. The knowledge produced has a specific temporal location; change is not its concern.

Such knowledge has great value. It answers often highly important questions. It correctly insists that in order to gain knowledge of a foreign legal system's laws, one needs to focus on how that system solves concrete problems at a specific moment. Skill in identifying and analyzing these normative treatmentswhether for scholarly purposes or in the context of a judge's, arbitrator's or legal practitioner's decisions-is the basic skill of a comparatist. Effective use of the method requires patient, careful analysis.

\section{What the Lenses Exclude from our Field of Vision}

But these lenses also tend to exclude much from our field of vision, and much of what they exclude is of growing importance. In discussing what is excluded from a category, one necessarily has to be selective, but I here note several elements that are particularly significant for assessing the contemporary role of Rabel's methods.

\section{Process}

As noted, those methods generally pay little attention to the processes that create the artifacts of law. Who made the decisions that yielded a particular legal rule? Which factors influenced the decision-making process? Such questions are not the focus of the inquiry. In some cases, contextual analysis might touch upon them, but answering them is not the primary objective. Rabel himself considered issues of process important, but the methods developed by him provide little incentive to explore them carefully. In general, the focus on artifacts tends to marginalize process issues. There is little incentive to investigate how a particular solution was achieved; the issue is the solution itself.

\section{Theory, Patterns and Relationships}

The method also excludes knowledge about connections between individual applications of the method. It does not relate knowledge resulting from one application to knowledge derived from other applications of those methods. There is no common theoretical or conceptual framework for organizing knowledge and relating discrete pieces of information to each other. Indeed, theorythe conceptual structuring of knowledge-is largely absent from Rabel's knowledge field. 


\section{Dynamics of Systems}

Rabel's methods produce little information about the dynamics of systems. They do not ask how a system has developed over time or what factors have influenced change. They are not directly interested in questions about how a problem was handled yesterday or what factors might be at work to change how it will be handled tomorrow. In this sense, the specific temporal location of the knowledge produced often obscures the relationship of that specific location to other points in time-past or future. Moreover, the method produces little knowledge of the "personality" of a legal system. Such a system is examined in relation to its production of particular artifacts, but the dynamics of how and why it operates as it does are of little direct concern. Here again Rabel appears to have been personally interested in some of these issues, but the methods create few incentives to pay attention to them.

\section{Communication Issues: Transferring Knowledge}

The knowledge produced is also minimally transferable. The methods neither provide nor utilize a language that is designed to convey information about the objects under investigation. Moreover, there is little incentive to transfer the information the methods produce. The knowledge produced by one application is likely to have little value for other potential users of the method, and they are therefore not likely to seek it. If knowledge does not have significance beyond its own specific context, only those who are interested in that context-here, the specific normative arrangement - have incentives to seek it.

\section{Public Law and Procedure}

The dominance of Rabel's methods has also tended to exclude issues of public law, procedure and regulation from comparative law study. There are many reasons for the private law bias of comparative law, but the structure of the dominant methodology undoubtedly plays a role. The process of identifying a concrete problem and then looking at how each legal system involved in the comparison treats that problem is relatively straightforward in private law areas such as contract or tort law. Contracts and injuries are part of an identifiable "concrete reality" to which each system must address answers. Contract law, for example, must address the issue of what makes the contract binding, what happens when there is no "meeting of the minds" in the contracting process and so on. Having done so, one need only look at the respective doctrinal treatments of the problem. The analysis may be complex, but the factual situation provides an identifiable structure outside the framework of legal concepts. In public and procedural law, on the other hand, application of Rabel's methods tends to be 
more problematic. ${ }^{41}$ For example, although procedural systems have some common elements, there is often no specific "life-situation" that can be extracted from the procedural context and compared to the same life-situation in another procedural system. Procedural systems create their own "reality" based on interrelated concepts and institutions. To that extent, the "concrete reality" that is necessary for applying Rabel's methods is missing.

\section{Contemporary Needs}

This sketch of the knowledge field produced by Rabel's methods helps to locate comparative law and suggests directions for further development of the discipline that Rabel played such a key role in establishing. Legal practice and scholarship today often call for knowledge and skills that Rabel's lenses do not capture or capture only to a limited extent and that therefore have little or no place in the field of vision of those who rely exclusively on those lenses. The increasing globalization of economic activity, for example, increases the need to understand the processes of communication among legal professionals and to enhance the capacity of those professionals effectively to interpret conduct and decisions across the boundaries of legal systems. As the speed and density of communication flows increase, the patient and detailed analysis of specific normative configurations needs to be combined with skills designed to recognize patterns in legal information and language, to perceive obstacles to effective communication among legal actors, and to discern the dynamics of the legal processes that produce a system's rules, principles and procedures. For achieving each of these objectives, the role of language will have to be central.

\section{CONCLUDING PERSPECTIVES}

Born of a desire to use comparative law to avoid the horrors of war and the terrors of social disintegration, Ernst Rabel's comparative law project was initially overwhelmed by the forces against which it was ranged. Once these forces were spent or destroyed, however, his project acquired an extraordinary degree of influence. In Germany, the United States and many other countries, his conception of comparative law became the standard vantage point for thinking about what comparative law was and how it should be done.

His methods represented an exceptionally important conceptual breakthrough, and we dare not forget how important they have been and continue to be. They provide a powerful tool of analysis that has been used to create an extensive and invaluable body of comparative law materials dealing with how legal systems treat specific problems.

${ }^{41}$ For an effort to apply these methods to procedure, see David J. Gerber, "Extraterritorial Discovery and the Conflict of Legal Systems," 34 Am. J. Comp. L. 745, 748-67 (1986). 
Yet the success of those methods and their status as orthodoxy has also constrained. As with any orthodoxy, his methods have sometimes served as an end rather than a means to an end, thereby limiting intellectual inquiry instead of expanding it. In the role of orthodoxy, the creative tension of the methods has itself sometimes been obscured.

In creating a methodology for comparative law, Rabel sought to make comparative law "realistic." His central message was that the words of the law-its texts and the languages of those involved in it - can obstruct our view of what is actually happening. Therefore, Rabel claimed, we must penetrate behind language to the concrete realities of what is actually done.

Yet language is also the principal source of the information we seek, and thus understanding how it is used to convey and conceal information and to shape the interpretation and application of both concepts and facts is fundamentally important. It is central to our enterprise. Here, however, Rabel provides us with little guidance. In his concern with penetrating the facade of formal legal language, he paid little heed to the problems raised by actually using language to acquire and transmit the knowledge he was seeking.

We need to distrust and be skeptical of language, but we cannot afford to ignore it. I submit, therefore, that a prominent item on the agenda of comparative law should be to find ways to integrate language issues into its goals and methods. In doing so, comparative law's methods would move closer to achieving the lofty objectives that Ernst Rabel set for it. 